\title{
Antioxidant and Anti-Inflammatory Properties of Bioavailable Protein Hydrolysates from Lupin-Derived Agri-Waste
}

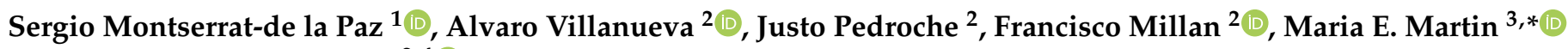 \\ and Maria C. Millan-Linares ${ }^{2,4}$ (iD \\ 1 Department of Medical Biochemistry, Molecular Biology, and Immunology, School of Medicine, Universidad \\ de Sevilla, Av. Sanchez Pizjuan s/n, 41009 Seville, Spain; delapaz@us.es \\ 2 Plant Protein Group, Food and Health Department, Instituto de la Grasa, CSIC. Ctra. de Utrera Km. 1, \\ 41013 Seville, Spain; alvarovillanueva@ig.csic.es (A.V.); jjavier@cica.es (J.P.); fmillanr@ig.csic.es (F.M.); \\ mcmillan@ig.csic.es (M.C.M.-L.) \\ 3 Department of Cell Biology, Faculty of Biology, Universidad de Sevilla, Av. Reina Mercedes s/n, \\ 41012 Seville, Spain \\ 4 Cell Biology Unit, Instituto de la Grasa, CSIC. Ctra. de Utrera Km. 1, 41013 Seville, Spain \\ * Correspondence: mariamartin@us.es; Tel.: +34-954557039
}

Citation: Montserrat-de la Paz, S.; Villanueva, A.; Pedroche, J.; Millan, F.; Martin, M.E.; Millan-Linares, M.C. Antioxidant and Anti-Inflammatory Properties of Bioavailable Protein Hydrolysates from Lupin-Derived Agri-Waste. Biomolecules 2021, 11, 1458. https://doi.org/10.3390/ biom 11101458

Academic Editors: Dominico

A. Guillén-Sánchez and

Valme García-Moreno

Received: 6 September 2021

Accepted: 1 October 2021

Published: 4 October 2021

Publisher's Note: MDPI stays neutral with regard to jurisdictional claims in published maps and institutional affiliations.

Copyright: (c) 2021 by the authors. Licensee MDPI, Basel, Switzerland. This article is an open access article distributed under the terms and conditions of the Creative Commons Attribution (CC BY) license (https:/ / creativecommons.org/licenses/by/ $4.0 /)$.

\begin{abstract}
Agri-food industries generate several by-products, including protein-rich materials currently treated as waste. Lupine species could be a sustainable alternative source of protein compared to other crops such as soybean or chickpea. Protein hydrolysates contain bioactive peptides that may act positively in disease prevention or treatment. Inflammatory responses and oxidative stress underlie many chronic pathologies and natural treatment approaches have gained attention as an alternative to synthetic pharmaceuticals. Recent studies have shown that lupin protein hydrolysates (LPHs) could be an important source of biopeptides, especially since they demonstrate anti-inflammatory properties. However, due to their possible degradation by digestive and brush-border enzymes, it is not clear whether these peptides can resist intestinal absorption and reach the bloodstream, where they may exert their biological effects. In this work, the in vitro cellular uptake/transport and the anti-inflammatory and antioxidant properties of LPH were investigated in a co-culture system with intestinal epithelial Caco-2 cells and THP-1-derived macrophages. The results indicate that the LPH crosses the human intestinal Caco-2 monolayer and exerts anti-inflammatory activity in macrophages located in the basement area by decreasing mRNA levels and the production of pro-inflammatory cytokines. A remarkable reduction in nitric oxide and ROS in the cell-based system by peptides from LPH was also demonstrated. Our preliminary results point to underexplored protein hydrolysates from food production industries as a novel, natural source of high-value-added biopeptides.
\end{abstract}

Keywords: agri-lupin waste; by-products; bioeconomy; plant proteins; anti-inflammatory; antioxidant; bioavailability

\section{Introduction}

The United Nations (UN) Sustainable Development Goals (SDGs) aim to shrink the global food waste generated per capita along the food supply chain by up to $50 \%$ by 2030 [1]. Currently, protein-rich agri-industrial waste is generated, among which is the flour or defatted flours from legumes and oilseed, and which constitute an important source for obtaining protein concentrate and isolates [2,3]. Green industries, such as those that produce industrial agricultural lupin, offer opportunities for more long-term benefits through sustainable regenerative farming practices. The industrial lupin market in Europe, which reached a size of 284 million in 2019, is expected to become profitable by 2027, growing at a rate of $4.39 \%$ in the forecast period 2020-2027 [4]. Growing concerns about food issues, as well as strict national and European regulations, make functional food an added value for the agri-food sector, given the economic impact of the commercialization 
of this type of product. In the literature, several works refer to the use of different parts of lupine such as whole grains and defatted flour, among others [5-8]. Lupin seed protein content is high (up to $44 \%$ ) and of good quality, offering potential health benefits, and contributing to the sustainability of cropping systems [9-11].

Chronic inflammation and oxidative stress play a key role in the development and progression of many chronic diseases such as autoimmune diseases, metabolic disorders, cardiovascular diseases, central nervous system-related disorders, fibrosis, diabetes, obesity, and cancer [12-14]. Diet is one of the major risk factors for the development of chronic diseases, so the modification of diet could prevent or delay the onset of these diseases. In this sense, functional foods and nutraceuticals have emerged as potential tools to improve health and well-being, and reduce the risk or delay the onset of major diseases, in concomitance with a reduction in side effects inherent to synthetic pharmaceuticals. One of the components of functional foods are bioactive peptides, which mostly contain 3-20 amino acid units, and are often encrypted in the native sequence of proteins and can be released by digestive enzymes during food processing or by in vitro hydrolysis by proteolytic enzymes [15]. Bioactive peptides can be classified according to their mode of action as antimicrobial, antithrombotic, antihypertensive, opioid, immunomodulatory, mineral-binding, and antioxidative [16]. These multifunctional activities can occur through different molecular and signaling mechanisms, passive paracellular transport, transportermediated active transport (via the PepT1), and transcytosis [17]. The intestinal absorption of carbohydrates such as glucose and lipids is well known; however, most of the mediators involved in the transport of peptides at the intestinal level have not yet been identified.

Bioactive peptides are widely available from protein hydrolysates in the plant kingdom, considering that most of the population's protein needs are covered with plant-based foods. On the other hand, food manufacturers produce large amounts of protein-rich by-products or waste from plants, with the main plant-protein sources being oilseeds, cereals, and legumes $[18,19]$. Thus, nutritional properties of natural protein hydrolysates as agri-food processing compounds have increased in interest during recent years. Indeed, proper nutrition may connect with the desirable concern about environmental impact derived from industrial activities [19]. One important aspect of bioactive peptides is their bioavailability. To exert their effects, peptides need to resist degradation by gastrointestinal proteases and brush-border peptidases, be absorbed through the intestinal epithelium, and reach the bloodstream in an active form [20,21]. Caco-2 is a cell line used to predict absorption in the small intestine, since differentiated Caco-2 cells maintain the morphology and function of mature enterocytes, and express brush-border peptidases and transporters that may affect the bioactivity of peptides [20,22].

In previous studies, we have described that lupin protein hydrolysates (LPHs) have potential anti-inflammatory properties due to the inhibition of enzymes involved in the inflammatory pathway [23] and the decrease in production and expression of pro-inflammatory cytokines in THP-1-derived macrophages [24] and osteoclasts [25]. The main aim of this manuscript was to study whether an LPH with anti-inflammatory properties may pass through the intestinal lumen and reach the bloodstream, so that bioactive peptides found in LPH are also bioavailable. Additionally, we studied the potential antioxidant effects of LPH peptides, measuring nitrite production and ROS levels. For these purposes, we tested an LPH in a co-culture system with Caco-2 cells and THP-1-derived macrophages stimulated with lipopolysaccharides (LPS). To the best of our knowledge, this is the first paper simultaneously measuring the bioavailability and bioactivity of plant-protein hydrolysates, an underexplored agri-food waste with health-promoting properties, in a cell-based system, providing opportunities for future research in tissue and organ models.

\section{Materials and Methods}

\subsection{Materials and Reagents}

Lupin protein isolate (LPI) was obtained in a pilot plant of vegetable proteins obtained from defatted lupin flour, as described by Millan-Linares et al. [23]. Alcalase ${ }^{\circledR} 2.4 \mathrm{~L}$ 
(2.4 AU/g), a non-specific serine endopeptidase, was provided by Novozymes (Bagsværd, Denmark). The cell types used were THP-1 monocytes (ATCC Number TIB-202) and Caco-2 (ATCC Number HBT-37). Culture media, fetal bovine serum (FBS), penicillin (P), and streptomycin (S) were from Gibco (Life Technologies SA, Spain). Phorbol 12-myristate 13-acetate (PMA) and LPS from Escherichia coli O55:B5 were purchased by Sigma Chemical Co. (St. Louis, MO, USA). Co-cultures were prepared in 12-well Millicell ${ }^{\circledR}$ plates with hanging cell-culture inserts $0.4 \mu \mathrm{m}$ PET (Millipore Corporation, Billerica, MA, USA). The iScript cDNA Synthesis Kit was obtained from Bio-Rad Laboratories (Hercules, CA, USA). Brilliant II SYBR Green QPCR Master Mix was purchased from Agilent Technologies (Santa Clara, CA, USA). All other reagents were of analytical grade.

\subsection{Preparation of Lupin Protein Hydrolysate}

Hydrolysis was performed in a bioreactor of the pilot plant of vegetable proteins, under stirring at a controlled $\mathrm{pH}$ and temperature. LPI was suspended in distilled water $(10 \% \mathrm{w} / \mathrm{v})$ and hydrolyzed with Alcalase ${ }^{\circledR}$ for $15 \mathrm{~min}$ at $\mathrm{pH} 8,50^{\circ} \mathrm{C}$, and $\mathrm{E} / \mathrm{S}=0.3 \mathrm{AU} / \mathrm{g}$ protein. The enzyme was inactivated through heating at $85^{\circ} \mathrm{C}$ for $15 \mathrm{~min}$. The supernatant obtained after centrifugation at $8000 \mathrm{rpm}$ for $15 \mathrm{~min}$ constituted the LPH.

\subsection{Analytical Methods}

The protein concentrations were determined by elemental microanalysis as a percentage of nitrogen content x 6.25 using a Leco CHNS-932 analyzer (St. Joseph, MI, USA). Ash content was determined by the direct ignition method $\left(550^{\circ} \mathrm{C}\right.$ for $\left.25 \mathrm{~h}\right)$. Total dietary fiber was determined according to a method presented by Lee et al. [26]. Oil content was measured using the AOAC (Association of Official Analytical Chemists) method 945.16 [27]. Polyphenols and soluble sugars were measured using chlorogenic [28] and glucose [29] standard curves, respectively. Amino acid composition was evaluated according to a method proposed by Alaiz et al. [30]. Tryptophan content was analyzed as described by Yust et al. [31].

\subsection{Caco-2 Culture}

Caco-2 cells were cultured in 12-well cell culture inserts in Dulbecco's Modified Eagle Medium, supplemented with 10\% heat-inactivated FBS and 1\% P/S. Cells were incubated at $37^{\circ} \mathrm{C}$ under a modified atmosphere of $5 \% \mathrm{CO}_{2}$ and given a fresh medium every 2-3 days. Cell monolayer integrity was monitored by trans-epithelial electrical resistance using a Millicell® ERS-2 voltammeter (Millipore). Inserts were used for 3 weeks after seeding, and had a resistance of at least $500 \Omega / \mathrm{cm}^{2}$.

\subsection{THP-1 Culture}

The human monocytic THP-1 cell line was cultured in a suspension of RPMI 1640 supplemented with $10 \%$ heat-inactivated FBS and $1 \% \mathrm{P} / \mathrm{S}$. Cells were seeded at $3 \times 10^{5}$ cells/well in 12-well plates and differentiated to macrophage-like cells by treatment for 4 days with PMA at $100 \mathrm{nmol} / \mathrm{L}$ [24].

\subsection{In Vitro Availability Using Caco-2/THP-1 Co-Cultures}

Inserts were transferred to 12 -well plates containing THP-1-derived macrophages. Treatments, after in vitro stimulation with or without LPS $(100 \mathrm{ng} / \mathrm{mL})$, were carried out under the same standard incubation conditions, and were initiated by replacing the medium with fresh medium containing LPH at 0.1 and $0.5 \mathrm{mg} / \mathrm{mL}$ in the apical chamber. After $24 \mathrm{~h}$, the supernatant in the basolateral side was recovered and RNA from THP-1derived macrophages cells stimulated with LPS was extracted.

\subsection{Reactive Oxygen Species Determination}

For the determination of the intracellular concentration of ROS, the fluorescent probe, $2^{\prime}, 7^{\prime}$-dichlorofluorescein diacetate (DCFDA), a fluorogenic dye that measures hydroxyl, 
peroxyl, and other ROS activity within the cell, was used. After diffusion into the cell, DCFDA was deacetylated by cellular esterases into a non-fluorescent compound, which was later oxidized by ROS into $2^{\prime}, 7^{\prime}$-dichlorofluorescein (DCF), a highly fluorescent compound, quantified by flow cytometry at $485 \mathrm{~nm}$ (excitation) and $535 \mathrm{~nm}$ (emission) [32].

\subsection{Nitric Oxide Assay}

THP-1-derived macrophages were seeded in a 96-well plate at a density of $5 \times 10^{5}$ cells per well and incubated overnight. Cells were pre-treated with both concentrations of LPH ( 0.5 to $10 \mathrm{mg} / \mathrm{mL}$ ) for $24 \mathrm{~h}$. After the treatments, culture supernatants were collected, and the nitric oxide (NO) concentration was measured using a Griess reagent assay kit (R\&D Systems, Inc. Minneapolis, MN, USA), which measures the level of accumulated nitrite, a NO metabolite. Absorbance was determined to be $540 \mathrm{~nm}$ [32].

\subsection{RNA Extraction and Analysis by RT-qPCR}

Total RNA was extracted from LPS-stimulated-THP-1 cells using NucleoSpin RNA II. RNA quality was assessed using the $\mathrm{OD}_{260}: \mathrm{OD}_{280}$ ratio determined by a NanoDrop ND1000 Spectrophotometer (Thermo Scientific, Waltham, MA, USA). One microgram of total RNA was subjected to RT-PCR testing to obtain cDNA according to the manufacturer's protocol. The mRNA levels for specific genes were determined using an Mx3000P Real-Time PCR System (Stratagene, La Jolla, CA, USA). For each qPCR, $10 \mathrm{ng}$ of cDNA template was added to the Brilliant SYBR Green qPCR Master Mix containing primer pairs for TNF- $\alpha$, IL-6, IL-1 $\beta$, and IL-10. The reference genes HPRT and GAPDH were used to correct for RNA concentration differences between the samples. The sequence of and information concerning the primers that were used in this study are as follows: TNF- $\alpha$ (NM_000594.3): $5^{\prime}$-TCCTTCAGACACCCTCAACC-3' ${ }^{\prime}$ and $5^{\prime}$-AGGCCCCAGTTTGAATTCTT-3' (reverse); IL-1 $\beta$ (NM_138712): 5'-GCTGTGCAGGAGATCACAGA-3' and 5'-GGGCTCCATAAAG TCACCAA-3' ${ }^{\prime}$ IL-6 (NM_001001928): 5'-GTTTGAGGGGGTAACAGCAA-3' and 5'-GCTAA CTGCAGAGGGTGAGG-3'; IL-10 (NM_000572.2): 5'-GTTCTTTGGGGAGCCAACAG-3' and 5'-GCTCCCTGGTTTCTCTTCCT-3'; HPRT (NM_000194.2): 5'-ACCCCACGAAGTGT TGGATA-3 ${ }^{\prime}$ and $5^{\prime}$-AAGCAGATGGCCACAGAACT-3'; and GAPDH (NM_002046.4): $5^{\prime}-$ GAGTCAACGGATTTGGTCGT-3' ${ }^{\prime}$ and 5'-TTGATTTTGGAGGGATCTCG-3'. All amplification reactions were performed in triplicate. The magnitude of the change in mRNA expression for the candidate genes was calculated using the standard $2^{-(\Delta \Delta \mathrm{Ct})}$ method. All data were normalized to the endogenous reference gene (HPRT and GAPDH) level, and expressed as a relative value of the control. The fold change was determined as follows: individual fold changes for all pairs of samples derived from the two groups to be compared were calculated, and the median of these individual fold changes represents the overall fold change for the given gene.

\subsection{Enzyme-Linked Immunosorbent Assay (ELISA)}

TNF- $\alpha$, IL-1 $\beta$, IL-6, and IL-10 concentrations in cell culture supernatants were quantified by commercial ELISA kits, according to the manufacturer's instructions.

\subsection{Statistical Analysis}

All values in the figures and text are expressed as the arithmetic mean $\pm \mathrm{SD}$. All experiments were carried out in triplicate, and repeated at least three times independently, with the exception of obtaining protein isolate and hydrolysates. The statistical analysis was performed with Graph Pad Prism Version 6.01 software (San Diego, CA, USA). The data were analyzed using a one-way analysis of variance (ANOVA), followed by Bonferroni tests for multiple comparisons. Differences were considered significant at $p<0.05$. 


\section{Results and Discussion}

\subsection{Chemical Characterization of LPH}

In previous studies, we reported that the hydrolysis of LPI with Alcalase ${ }^{\circledR}$ led to the production of LPHs with potential anti-inflammatory properties due to the inhibition of enzymes involved in the inflammatory route [23]. In this previous work, several hydrolysis timeframes were tested, and we concluded that LPH produced after 15 min showed the best effect. Specifically, this LPH inhibited 90\% COX-2, 22\% thrombin, and 50\% transglutaminase activity, whereas LPI inhibited 65\% COX-2, 5\% thrombin, and inhibition of transglutaminase activity was not detected [23]. Moreover, this LPH induced the downregulation of TNF, IL-1 $\beta$, and IL-6 in THP-1-derived macrophages [24].

The chemical composition of LPI and LPH is shown in Table 1. The protein content of LPI is above $86 \%$ on a dry basis; this value is similar to that obtained by other authors [33,34], and much higher than that of the starting flour with a protein richness of $39.91 \%$. The chemical composition of LPH was similar to LPI; the main difference between the two samples was ash content, which was higher in LPH. This is a normal consequence of the addition of alkali during the hydrolytic process to maintain the $\mathrm{pH}$ constant [35]. Consequently, the other components of LPH, with the exception of polyphenols, decreased. The amino acid composition of both products did not show significant differences (Table 2); this evidences that enzymatic hydrolysis does not alter the nutritional value of original proteins [35]. Furthermore, LPI and LPH showed an amino acid profile typical of lupin proteins, being the main components glutamic acid/glutamine, arginine, and aspartic acid/asparagine, and the minor ones sulfur amino acids and tryptophan [36]. Both products meet the nutritional requirements proposed by $\mathrm{FAO} / \mathrm{WHO}$, with the exception of sulfur amino acids, which are common in legume proteins $[35,37]$. Considering that LPI and LPH showed similar compositions, the increase in anti-inflammatory activity in LPH should be ascribed to the release, due to the hydrolytic process, of specific peptides encrypted in the protein sequences.

Table 1. Chemical composition of LPI and LPH. Data, expressed as percentage in dry basis, are mean \pm standard deviation of three determinations.

\begin{tabular}{ccc}
\hline $\mathbf{( \% )}$ & LPI & LPH \\
\hline Protein & $86.72 \pm 0.13$ & $83.70 \pm 0.09$ \\
Ash & $0.78 \pm 0.13$ & $8.98 \pm 0.09$ \\
Fibre & $5.97 \pm 0.34$ & $0.97 \pm 0.02$ \\
Oil & $5.14 \pm 0.17$ & $1.15 \pm 0.01$ \\
Soluble sugars & $0.04 \pm 0.00$ & $0.02 \pm 0.00$ \\
Polyphenols $^{\text {Others }}{ }^{1}$ & $0.01 \pm 0.00$ & $0.06 \pm 0.00$ \\
\hline
\end{tabular}

${ }^{1}$ measured as 100-protein-ash-fibre-oil-soluble sugars-polyphenols.

Table 2. Amino acid composition of LPI and LPH. Data, expressed as percentage of amino acids on total amino acid content, are mean \pm standard deviation of three determinations.

\begin{tabular}{cccc}
\hline & LPI & LPH & FAO/WHO [38] \\
\hline Asp+ Asn & $10.68 \pm 0.27$ & $10.27 \pm 0.12$ & \\
Glu+Gln & $23.06 \pm 0.40$ & $24.47 \pm 0.17$ & \\
Ser & $5.96 \pm 0.05$ & $5.97 \pm 0.16$ & 1.5 \\
His & $2.39 \pm 0.15$ & $2.36 \pm 0.01$ & \\
Gly & $4.47 \pm 0.17$ & $4.52 \pm 0.06$ & \\
Thr & $3.88 \pm 0.19$ & $4.05 \pm 0.02$ & \\
Arg & $11.78 \pm 0.02$ & $11.60 \pm 0.06$ & \\
Ala & $3.80 \pm 0.04$ & $3.89 \pm 0.07$ & \\
Pro & $0.75 \pm 0.01$ & $0.75 \pm 0.01$ & \\
Tyr & $4.27 \pm 0.39$ & $4.42 \pm 0.12$ & \\
\hline
\end{tabular}


Table 2. Cont.

\begin{tabular}{cccc}
\hline & LPI & LPH & FAO/WHO [38] \\
\hline Val & $3.98 \pm 0.47$ & $3.47 \pm 0.07$ & 3.9 \\
Met & $0.37 \pm 0.00$ & $0.44 \pm 0.15$ & $2.2^{1}$ \\
Cys & $0.78 \pm 0.13$ & $0.56 \pm 0.19$ & \\
Ile & $4.83 \pm 0.04$ & $4.45 \pm 0.01$ & 3.0 \\
Leu & $8.71 \pm 0.03$ & $8.55 \pm 0.05$ & 5.9 \\
Phe & $5.06 \pm 0.01$ & $4.95 \pm 0.01$ & $3.8^{2}$ \\
Lys & $4.87 \pm 0.00$ & $4.92 \pm 0.02$ & 4.5 \\
Trp & $0.38 \pm 0.03$ & $0.35 \pm 0.02$ & \\
\hline
\end{tabular}

${ }^{1}$ Met + Cys, ${ }^{2}$ Phe + Tyr.

\subsection{LPH Reduces Production of ROS and Nitrites in LPS-Stimulated THP-1-Derived Macrophages}

Caco-2 monolayers are widely used to predict transport via different pathways across the intestinal lumen $[21,39,40]$. In order to study the bioavailability of antioxidant and antiinflammatory peptides in LPH, co-cultures of Caco-2 and THP-1-derived macrophage in 12-well Millicell@ plates with hanging inserts were used. This system has two compartments, and a Caco-2 monolayer separates the apical zone, corresponding to the intestinal lumen, from the basolateral one, corresponding to the intestinal vascular and blood circulation system (Figure 1).

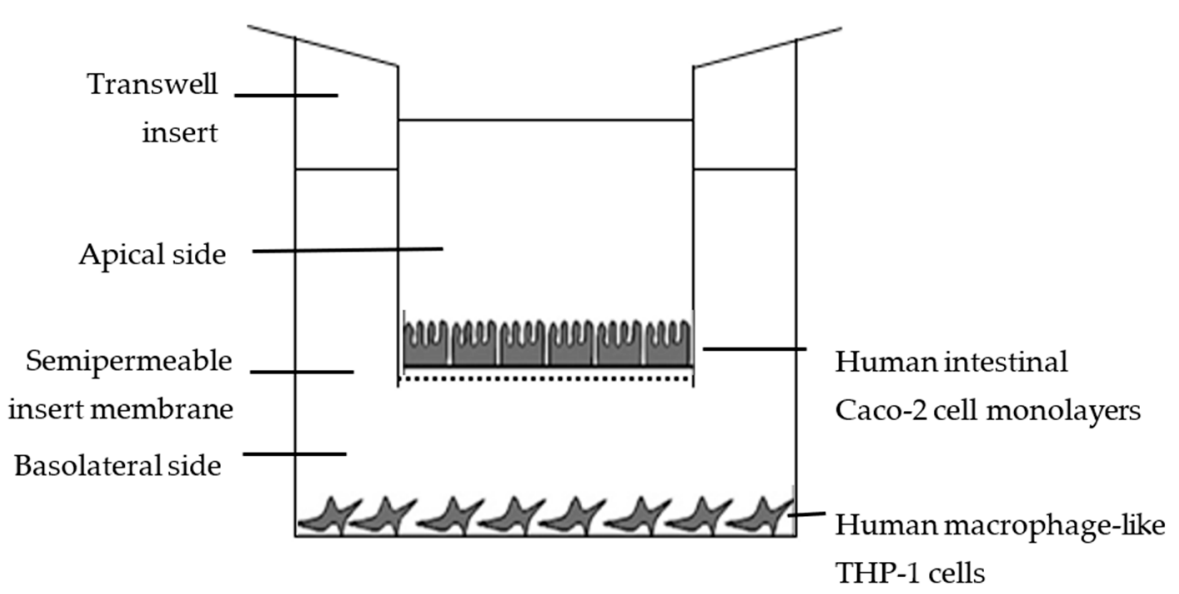

Figure 1. Schematic representation of the co-culture system of Caco-2 monolayer and LPS-stimulated THP-1-derived macrophages.

The co-cultures were treated with 0.1 and $0.5 \mathrm{mg} / \mathrm{mL}$ of LPH and, after $24 \mathrm{~h}$, the basolateral supernatant was recovered to measure biological activities. Two controls without LPH were studied, and consisted in THP-1-derived macrophages without LPH (control) and with LPS stimulation (control+LPS). As shown in Figure 2A, intracellular ROS production decreased by less than half in LPS-induced conditions in the presence of both LPH doses, almost restoring the control percentage after treatment with $0.5 \mathrm{mg} / \mathrm{mL}$ of LPH. In line with these effects, Figure 2B shows an LPH dose-dependent decrease in nitrite release to the culture medium in LPS-stimulated cells, under 50\% nitrite values in the presence of $0.1 \mathrm{mg} / \mathrm{mL} \mathrm{LPH}$, and a similar percentage to non-stimulated conditions after $0.5 \mathrm{mg} / \mathrm{mL}$ LPH treatment. As already stated, oxidative stress and inflammatory microenvironments are related to chronic diseases [14]. Antioxidant activities help to restore balance conditions caused by inflammation, cancer, or aging. Several protein hydrolysates and peptides with antioxidant effects from animals and plants, such as milk, fish, sesame or wheat brans, hemp or rapeseed, corn, or soy, have been tested both in vitro and in vivo with promising results $[18,19,41]$. Cell-based systems have also been useful to elucidate the detailed antioxidant mechanism of milk peptides [42,43], fish or seaweed 
protein hydrolysates [44], and hemp seed or rice endosperm proteins. Nevertheless, only a few studies, including those involving rapeseed hydrolysates, have been assessed in animal models for verifying antioxidant activities in biopeptides [14].

A

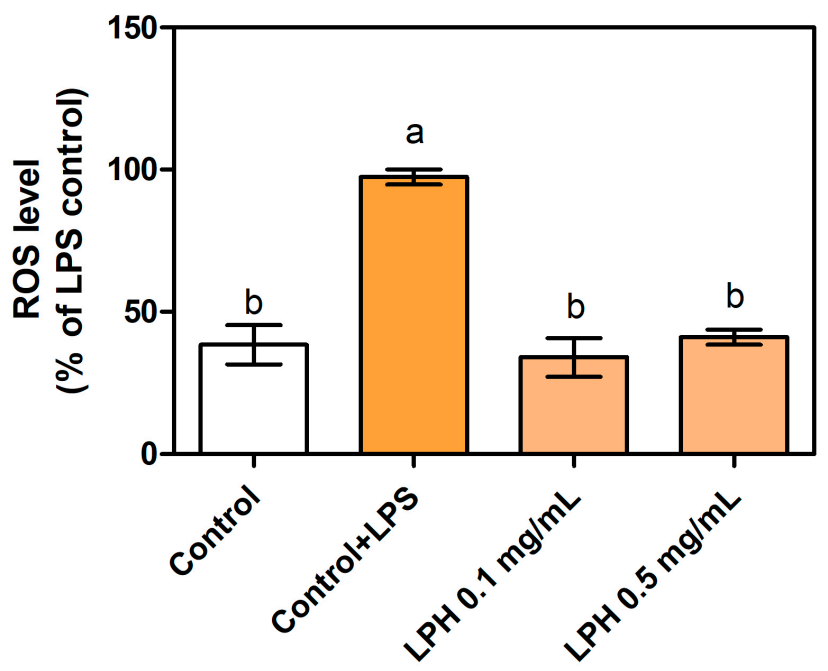

B

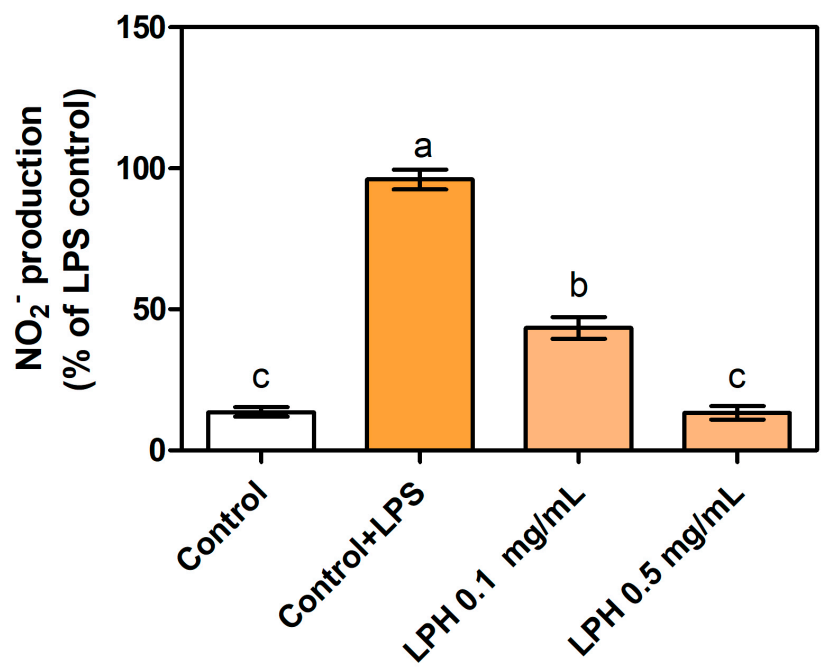

Figure 2. Intracellular ROS (A) and nitrite (B) production, expressed as percentage of fluorescence/absorbance after $24 \mathrm{~h}$ incubation with or without LPS $(100 \mathrm{ng} / \mathrm{mL})$ and LPH at 0.1 and $0.5 \mathrm{mg} / \mathrm{mL}$. Values are presented as means $\pm \mathrm{SD}(n=3)$ and those marked with different letters are significantly different $(p<0.05)$.

Our data focus on the antioxidant potential of LPH as a natural source of biopeptides that may exert their activity at target sites after crossing the gastrointestinal barrier. Bioavailability and oxidative balance recovery, as shown by LPH, provide an opportunity for the development of functional foods and the reduction in wastes from agri-industrial activities. 


\subsection{Effect of LPH on mRNA Expression of Pro-Inflammatory Cytokines}

In order to investigate whether LPH peptides could be absorbed through intestinal lumen and decrease cytokine production by the regulation of gene expression, we measured mRNA expression of TNF- $\alpha$, IL-1 $\beta$, IL- 6 and IL-10 in THP-1-derived macrophages co-cultured with Caco-2. Pro-inflammatory cytokine (TNF- $\alpha$, IL-1 $\beta$, and IL-6) mRNA expression increased threefold when THP-1 cells were stimulated with LPS. The addition of LPH to the culture medium decreased its mRNA expression up to the control values; in other words, the treatment with LPH returned to the inflammatory conditions in the unstimulated THP-1-derived macrophages. The effect of LPH was even more drastic in IL-1 $\beta$ mRNA expression, since the values were lower than in the control group (Figure 3). There were no significant differences between the two LPH concentrations tested. On the other hand, LPH increased mRNA levels of anti-inflammatory IL-10 cytokine after $24 \mathrm{~h}$ of treatments, but only at a concentration of $0.5 \mathrm{mg} / \mathrm{mL}$, indicating that the anti-inflammatory effect is dependent on the concentration of the hydrolysate.

A
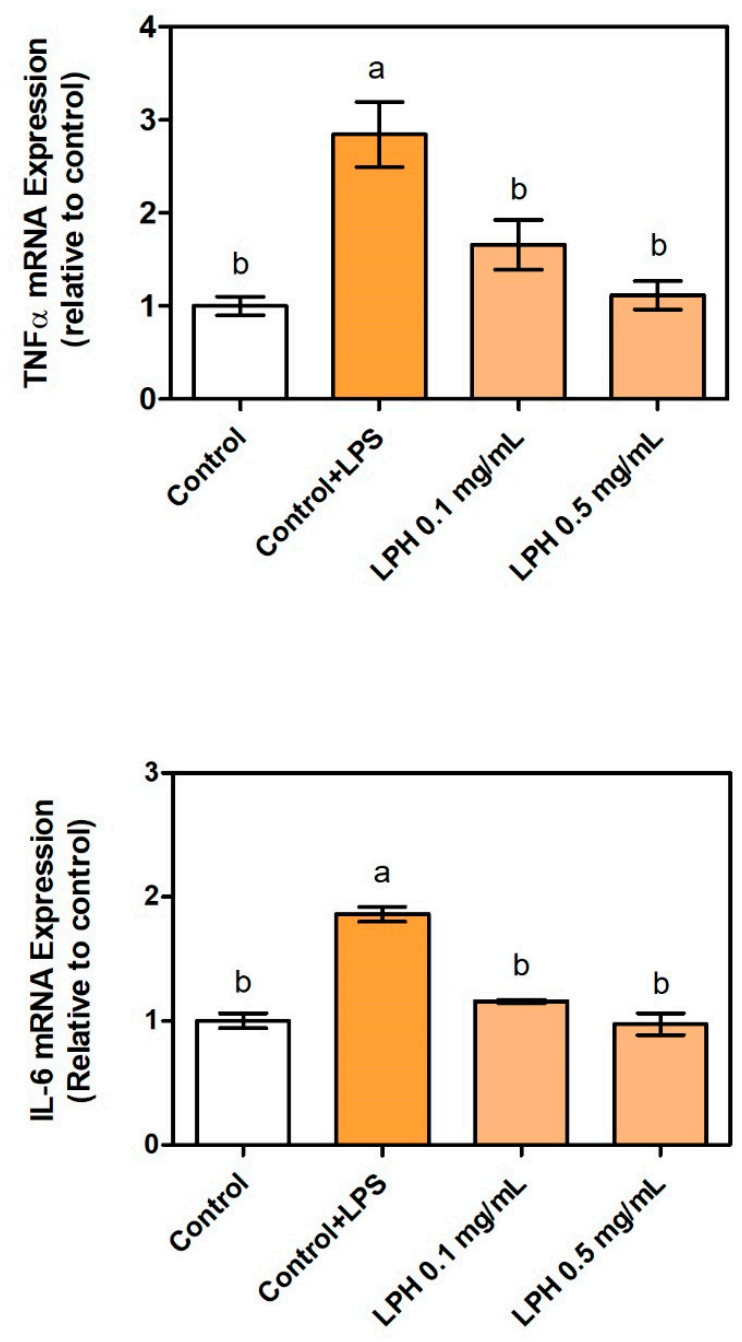

C
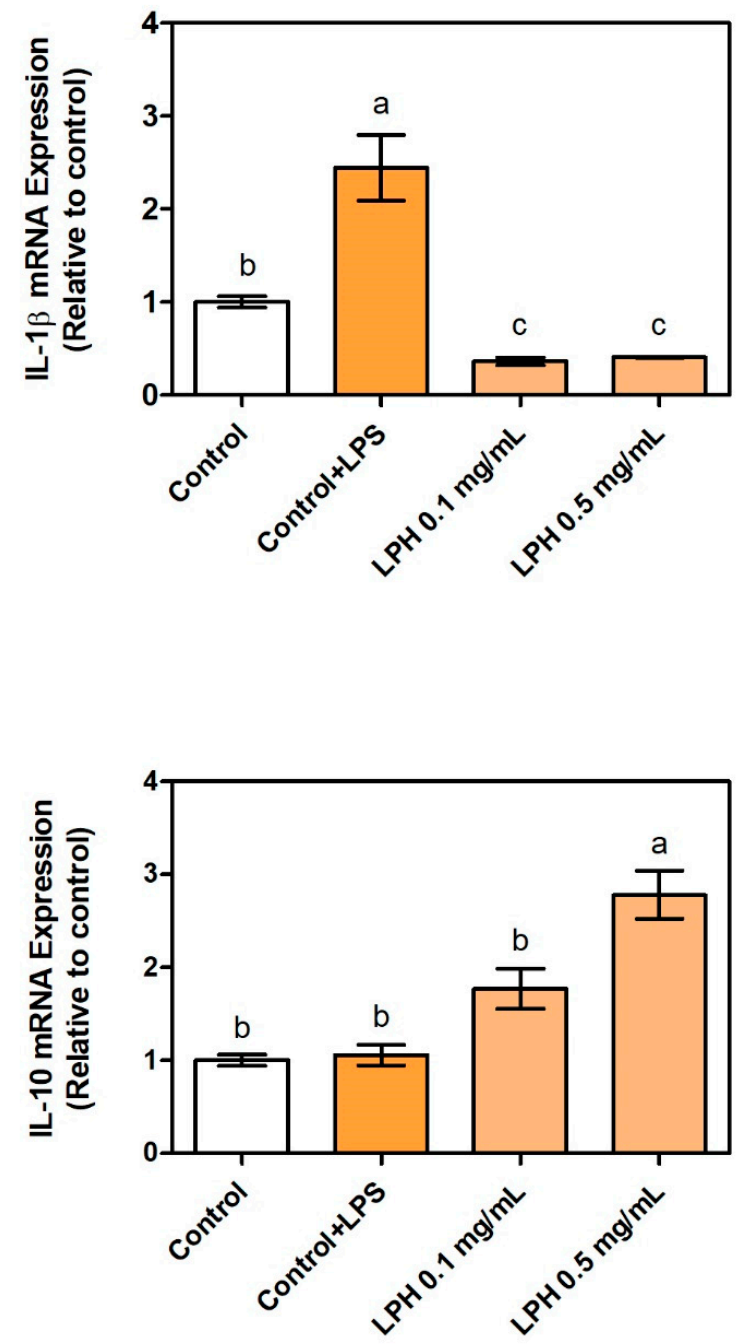

D

Figure 3. TNF- $\alpha$ (A), IL-1 $\beta$ (B), IL-6 (C), and IL-10 (D) mRNA expression in THP-1-derived macrophages co-cultured with Caco-2 cells in Millicell ${ }^{\circledR}$ system and treated with or without LPS $(100 \mathrm{ng} / \mathrm{mL})$ and $\mathrm{LPH}$ at 0.1 and $0.5 \mathrm{mg} / \mathrm{mL}$. Values are presented as means $\pm \mathrm{SD}(n=3)$ and those marked with different letters are significantly different $(p<0.05)$. 
The inflammatory responses that underlie many chronic diseases involve mediators such as pro-inflammatory cytokines, chemokines, and reactive oxygen species, affecting a wide range of cells. Due to the complex and multisystem events that occur during inflammation, it is necessary to develop many approaches to investigate both the expression and the presence of these markers in cell-based systems [14]. Protein-rich by-products from animal- and plant-processing industries have previously demonstrated a key role during inflammation due to the presence of bioactive isolated peptides or hydrolysates. With the exception of milk and egg components, in general, more studies with plant material have been carried out [14]. Our results of LPH decreasing the expression of pro-inflammatory cytokines are similar to others shown in plant-protein hydrolysates, such as wheat, gluten, or hemp $[45,46]$.

\subsection{Effect of LPH on the Production of Pro- and Anti-Inflammatory Cytokines}

Anti-inflammatory activity was tested by measuring the secretion of pro-inflammatory cytokines TNF- $\alpha$, IL-1 $\beta$, and IL6, and anti-inflammatory cytokine IL-10 by THP-1-derived macrophages, since they have been described as the major cytokines involved in inflammation [47]. The concentration of pro-inflammatory cytokines in the supernatant of THP1-derived macrophages stimulated with LPS (without LPH) was significantly raised in comparison with the control without LPS, demonstrating that THP-1-derived macrophages cells were effectively induced towards an inflammatory state. The treatment with LPH reduced the secretion of TNF- $\alpha$, IL-1 $\beta$, and IL- 6 up to control levels. There were no statistic differences when varying amounts of LPH were used, since both of them decreased the concentration of TNF- $\alpha$, IL- $1 \beta$, and IL- 6 by 70,40 , and $45 \%$, respectively (Figure 4 ). These results are even higher than those previously reported by our research group, since we found that TNF- $\alpha$ production was reduced by $31 \%$ by treatment with the same LPH that was used in this study [24]. However, results cannot be directly compared, since THP-1 cells were differentiated to macrophages with PMA in Millan-Linares et al. [24]. LPH peptides crossed Caco-2 monolayers, and the modifications produced during this process, if any, did not negatively affect the bioactive properties. Similar conclusions have been described about the potential absorption of lupin peptides with hypocholesterolemic activity in human intestinal cells [21,48]. Furthermore, it has been reported as a possible selective absorption of the most bioactive components as a way to explain higher bioactivity of peptides transported by Caco-2 cells in the basolateral compartment than in the starting sample [21]. Regarding the anti-inflammatory cytokine IL-10, only LPH at the highest concentration showed a significant increase in its production in relation to LPS-stimulated THP-1-derived macrophages. It has been previously described that LPH has an important effect on the production and expression of pro-inflammatory cytokines, but not on antiinflammatory cytokines [24]. The results of cytokine mRNA expression are consistent with cytokine production in the supernatant of culture medium, indicating that LPH acts at both the transcriptional and post-transcriptional levels. The same result was found when THP-1-derived macrophages were treated with a peptide purified from LPH [49]. 
A
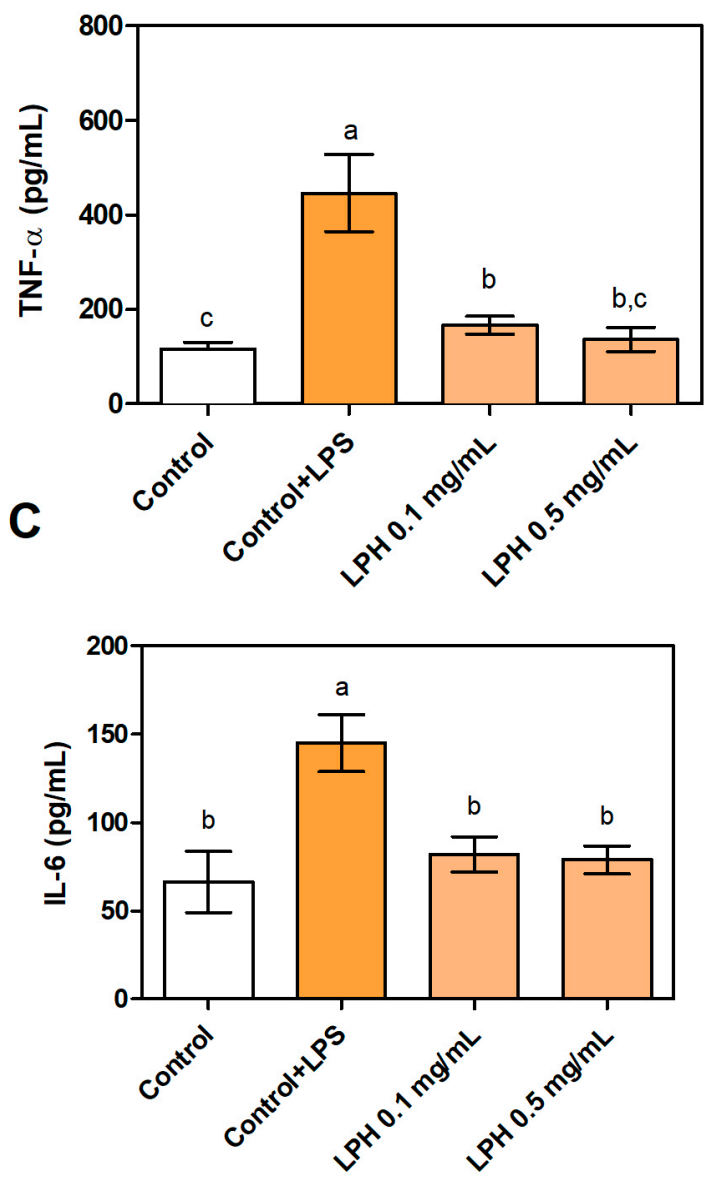

B
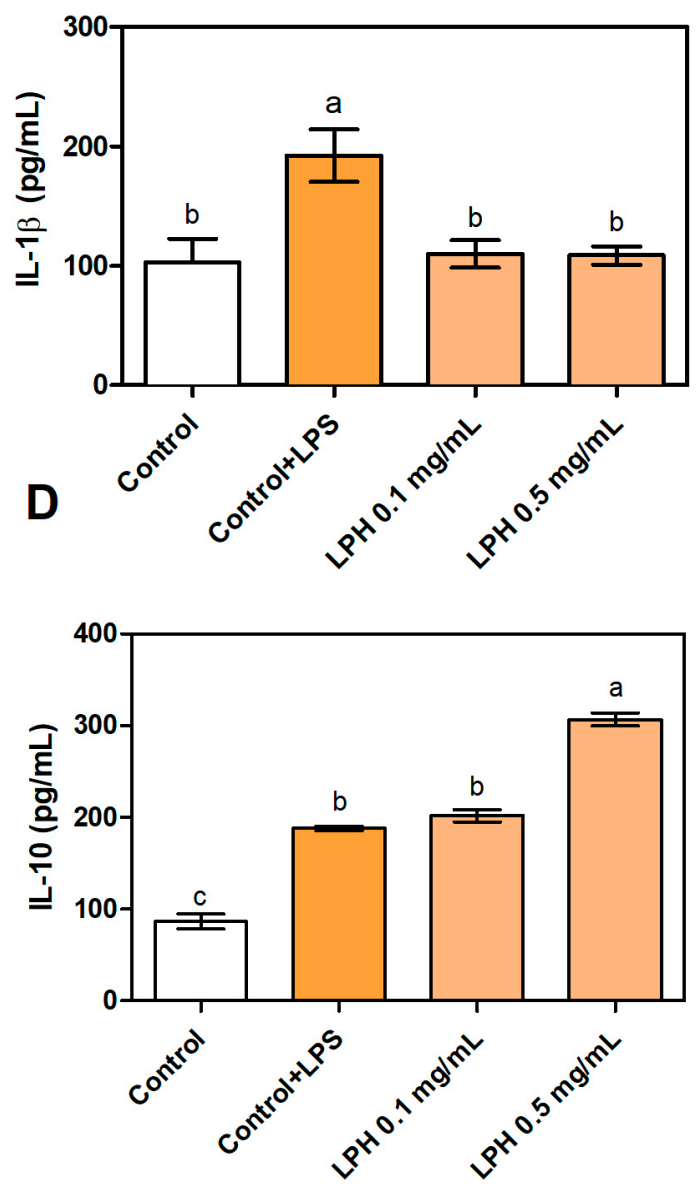

Figure 4. Production of (A) TNF- $\alpha$, (B) IL-1 $\beta$, (C) IL-6, and (D) IL-10 by THP-1-derived macrophages (Control), LPSstimulated THP-1-derived macrophages (Control+LPS), and Control+LPS treated with 0.1 (LPH 0.1 ) and $0.5 \mathrm{mg} / \mathrm{mL}$ (LPH 0.5) of LPH. In all cases, THP-1 cells were co-cultured with Caco-2 cells in Millicell@ systems. Values marked with different letters are significantly different $(p<0.05)$.

\section{Conclusions}

We have demonstrated that antioxidant and anti-inflammatory peptides in LPH are potentially resistant to the gastrointestinal tract and may reach the bloodstream to exert their beneficial effects. Bioactivity of LPH from protein-rich by-products created during agri-industrial processes emphasize the valuation of traditional wastes as highadded-value products reducing the environmental impact of human activities. Due to the strong relationship between chronic inflammation, involving oxidative stress, and several chronic diseases, LPH (bioavailable and bioactive) may be excellent ingredients of functional foods or nutraceuticals, as a tool for fighting against these diseases and their risk factors, minimizing side effects compared to traditional therapies. Our study points to specific receptors and signaling pathways that mediate the anti-inflammatory and antioxidant molecular mechanisms of beneficial actions of lupin hydrolysates. However, further studies regarding peptides sequences, molecular receptors, and immunogenicity, must be performed to confirm these properties in vivo and translate this knowledge to a tissue and organ level, to fully exploit the potential of plant industry by-products which are rich in proteins and peptides. 
Author Contributions: Conceptualization, S.M.-d.1.P., M.C.M.-L.; methodology, M.E.M., A.V.; formal analysis, M.E.M.; investigation, M.C.M.-L., S.M.-d.1.P.; resources, A.V. data curation, M.E.M., A.V.; writing-original draft preparation, M.C.M.-L.; writing—review and editing, S.M.-d.1.P.; funding acquisition, F.M., J.P. All authors have read and agreed to the published version of the manuscript.

Funding: This research was funded by grant CYTED-2019/119RT0567 from the Spanish Ministry of Science, Innovation, and Universities.

Institutional Review Board Statement: Not applicable.

Informed Consent Statement: Not applicable.

Data Availability Statement: Not applicable.

Acknowledgments: Authors thank Cell Biology Unit of Instituto de la Grasa for its assistance during the fulfillment of this work.

Conflicts of Interest: The authors declare no conflict of interest.

\section{References}

1. Kamal, H.; Le, C.F.; Salter, A.M.; Ali, A. Extraction of protein from food waste: An overview of current status and opportunities. Compr. Rev. Food Sci. Food Saf. 2021, 20, 2455-2475. [CrossRef]

2. Joehnke, M.S.; Jeske, S.; Ispiryan, L.; Zannini, E.; Arendt, E.K.; Bez, J.; Sørensen, J.C.; Petersen, I.L. Nutritional and anti-nutritional properties of lentil (Lens culinaris) protein isolates prepared by pilot-scale processing. Food Chem. X 2021, 9, 100112. [CrossRef] [PubMed]

3. Akharume, F.U.; Aluko, R.E.; Adedeji, A.A. Modification of plant proteins for improved functionality: A review. Compr. Rev. Food Sci. Food Saf. 2021, 20, 198-224. [CrossRef] [PubMed]

4. Lupin Market Global Industry Trends and Forecast to 2027 Data Bridge Market Research. Available online: https://www. databridgemarketresearch.com/reports/global-lupin-market (accessed on 5 September 2021).

5. Bartkiene, E.; Sakiene, V.; Bartkevics, V.; Juodeikiene, G.; Lele, V.; Wiacek, C.; Braun, P.G. Modulation of the nutritional value of lupine wholemeal and protein isolates using submerged and solid-state fermentation with Pediococcus pentosaceus strains. Int. J. Food Sci. Technol. 2018, 53, 1896-1905. [CrossRef]

6. Łopusiewicz, Ł.; Drozłowska, E.; Trocer, P.; Kwiatkowski, P.; Bartkowiak, A.; Gefrom, A.; Sienkiewicz, M. The Effect of Fermentation with Kefir Grains on the Physicochemical and Antioxidant Properties of Beverages from Blue Lupin (Lupinus angustifolius L.) Seeds. Molecules 2020, 25, 5791. [CrossRef] [PubMed]

7. Karamać, M.; Orak, H.H.; Amarowicz, R.; Orak, A.; Piekoszewski, W. Phenolic contents and antioxidant capacities of wild and cultivated white lupin (Lupinus albus L.) seeds. Food Chem. 2018, 258, 1-7. [CrossRef]

8. Khan, M.K.; Karnpanit, W.; Nasar-Abbas, S.M.; Huma, Z.-E.; Jayasena, V. Phytochemical composition and bioactivities of lupin: A review. Int. J. Food Sci. Technol. 2015, 50, 2004-2012. [CrossRef]

9. Abraham, E.M.; Ganopoulos, I.; Madesis, P.; Mavromatis, A.; Mylona, P.; Nianiou-Obeidat, I.; Parissi, Z.; Polidoros, A.; Tani, E.; Vlachostergios, D. The Use of Lupin as a Source of Protein in Animal Feeding: Genomic Tools and Breeding Approaches. Int. J. Mol. Sci. 2019, 20, 851. [CrossRef]

10. Mota, J.; Lima, A.; Ferreira, R.B.; Raymundo, A. Lupin Seed Protein Extract Can Efficiently Enrich the Physical Properties of Cookies Prepared with Alternative Flours. Foods 2020, 9, 1064. [CrossRef]

11. Ruiz López, F.J. Hidrolizado de Proteínas de Chícharo (Pisum sativum) y Arroz (Oryza sativa) y Su Efecto Antiadipogénico in Silico. Ph.D. Thesis, Universidad Autónoma de Nuevo León, San Nicolás de los Garza, Mexico, 2020.

12. Fleit, H. Chronic Inflammation. Pathobiol. Hum. Dis. A Dyn. Encycl. Dis. Mech. 2014, 2014, 300-314. [CrossRef]

13. Majumder, K.; Mine, Y.; Wu, J. The potential of food protein-derived anti-inflammatory peptides against various chronic inflammatory diseases. J. Sci. Food Agric. 2015, 96, 2303-2311. [CrossRef]

14. Chakrabarti, S.; Jahandideh, F.; Wu, J. Food-Derived Bioactive Peptides on Inflammation and Oxidative Stress. BioMed Res. Int. 2014, 2014, 1-11. [CrossRef]

15. Rizzello, C.G.; Tagliazucchi, D.; Babini, E.; Rutella, G.S.; Saa, D.L.T.; Gianotti, A. Bioactive peptides from vegetable food matrices: Research trends and novel biotechnologies for synthesis and recovery. J. Funct. Foods 2016, 27, 549-569. [CrossRef]

16. Sánchez, A.; Vázquez, A. Bioactive peptides: A review. Food Qual. Saf. 2017, 1, 29-46. [CrossRef]

17. Guha, S.; Alvarez, S.; Majumder, K. Transport of Dietary Anti-Inflammatory Peptide, $\gamma$-Glutamyl Valine ( $\gamma$-EV), across the Intestinal Caco-2 Monolayer. Nutrients 2021, 13, 1448. [CrossRef] [PubMed]

18. Görgüç, A.; Gençdağ, E.; Yılmaz, F.M. Bioactive peptides derived from plant origin by-products: Biological activities and techno-functional utilizations in food developments A review. Food Res. Int. 2020, 136, 109504. [CrossRef] [PubMed]

19. Chakrabarti, S.; Guha, S.; Majumder, K. Food-Derived Bioactive Peptides in Human Health: Challenges and Opportunities. Nutrients 2018, 10, 1738. [CrossRef] [PubMed]

20. Gallego, M.; Grootaert, C.; Mora, L.; Aristoy, M.C.; Van Camp, J.; Toldrá, F. Transepithelial transport of dry-cured ham peptides with ACE inhibitory activity through a Caco-2 cell monolayer. J. Funct. Foods 2016, 21, 388-395. [CrossRef] 
21. Lammi, C.; Aiello, G.; Vistoli, G.; Zanoni, C.; Arnoldi, A.; Sambuy, Y.; Ferruzza, S.; Ranaldi, G. A multidisciplinary investigation on the bioavailability and activity of peptides from lupin protein. J. Funct. Foods 2016, 24, 297-306. [CrossRef]

22. Xu, Q.; Hong, H.; Wu, J.; Yan, X. Bioavailability of bioactive peptides derived from food proteins across the intestinal epithelial membrane: A review. Trends Food Sci. Technol. 2019, 86, 399-411. [CrossRef]

23. Millán-Linares, M.D.C.; Yust, M.D.M.; Hidalgo, J.M.A.; Millán, F.; Pedroche, J. Lupine protein hydrolysates inhibit enzymes involved in the inflammatory pathway. Food Chem. 2014, 151, 141-147. [CrossRef] [PubMed]

24. Millán-Linares, M.D.C.; Bermúdez, B.; Yust, M.D.M.; Millán, F.; Pedroche, J. Anti-inflammatory activity of lupine (Lupinus angustifolius L.) protein hydrolysates in THP-1-derived macrophages. J. Funct. Foods 2014, 8, 224-233. [CrossRef]

25. Millán-Linares, M.D.C.; Lemus-Conejo, A.; Yust, M.M.; Pedroche, J.; Vico, A.C.; Millan, F.; La Paz, S.M.-D. GPETAFLR, a novel bioactive peptide from Lupinus angustifolius L. protein hydrolysate, reduces osteoclastogenesis. J. Funct. Foods 2018, 47, 299-303. [CrossRef]

26. Lee, S.C.; Prosky, L.; De Vries, J.W. Determination of Total, Soluble, and Insoluble Dietary Fiber in Foods-Enzymatic-Gravimetric Method, MES-TRIS Buffer: Collaborative Study. J. AOAC Int. 1992, 75, 395-416. [CrossRef]

27. Thiex, N. Evaluation of Analytical Methods for the Determination of Moisture, Crude Protein, Crude Fat, and Crude Fiber in Distillers Dried Grains with Solubles. J. AOAC Int. 2009, 92, 61-73. [CrossRef]

28. Moores, R.G.; Mcdermott, D.L.; Wood, T.R. Determination of Chlorogenic Acid in Coffee millimicrons of a mixture of phenolic compounds, including chlorogenic acid, which they found in sweet potatoes. Purification and properties of chlorogenic ACID. Anal. Chem. 1948, 28, 620-624. [CrossRef]

29. Dubois, M.; Gilles, K.A.; Hamilton, J.K.; Rebers, P.A.; Smith, F. Colorimetric Method for Determination of Sugars and Related Substances. Anal. Chem. 1956, 28, 350-356. [CrossRef]

30. Alaiz, M.; Navarro, J.L.; Giron-Calle, J.; Vioque, E. Amino acid analysis by high-performance liquid chromatography after derivatization with diethyl ethoxymethylenemalonate. J. Chromatogr. A 1992, 591, 181-186. [CrossRef]

31. Yust, M.D.M.; Pedroche, J.; Giron-Calle, J.; Vioque, J.; Millán, F.; Alaiz, M. Determination of tryptophan by high-performance liquid chromatography of alkaline hydrolysates with spectrophotometric detection. Food Chem. 2004, 85, 317-320. [CrossRef]

32. Castellano, J.M.; Garcia-Rodriguez, S.; Espinosa, J.M.; Millan-Linares, M.C.; Rada, M.; Perona, J.S. Oleanolic Acid Exerts a Neuroprotective Effect Against Microglial Cell Activation by Modulating Cytokine Release and Antioxidant Defense Systems. Biomolecules 2019, 9, 683. [CrossRef]

33. Lqari, H.; Vioque, J.; Pedroche, J.; Millán, F. Lupinus angustifolius protein isolates: Chemical composition, functional properties and protein characterization. Food Chem. 2002, 76, 349-356. [CrossRef]

34. Berghout, J.; Venema, P.; Boom, R.; van der Goot, A.J. Comparing functional properties of concentrated protein isolates with freeze-dried protein isolates from lupin seeds. Food Hydrocoll. 2015, 51, 346-354. [CrossRef]

35. Yust, M.D.M.; Pedroche, J.; Millán-Linares, M.D.C.; Hidalgo, J.M.A.; Millán, F. Improvement of functional properties of chickpea proteins by hydrolysis with immobilised Alcalase. Food Chem. 2010, 122, 1212-1217. [CrossRef]

36. Muranyi, I.S.; Volke, D.; Hoffmann, R.; Eisner, P.; Herfellner, T.; Brunnbauer, M.; Koehler, P.; Schweiggert-Weisz, U. Protein distribution in lupin protein isolates from Lupinus angustifolius L. prepared by various isolation techniques. Food Chem. 2016, 207, 6-15. [CrossRef]

37. Khalid, I.I.; Elhardallou, S.B.; Gubouri, A.A. Amino Acid Composition and Physicochemical Properties of Bitter Lupine (Lupinustermis) Seed Flour. Orient. J. Chem. 2016, 32, 3175-3182. [CrossRef]

38. FAO. Dietary Protein Quality Evaluation in Human Nutrition Report of an FAO Expert Consultation; FAO Food and Nutrition Paper, 92; FAO: Rome, Italy, 2013.

39. Artursson, P.; Palm, K.; Luthman, K. Caco-2 monolayers in experimental and theoretical predictions of drug transport. Adv. Drug Deliv. Rev. 2012, 64, 280-289. [CrossRef]

40. Shi, Y.; Kovacs-Nolan, J.; Jiang, B.; Tsao, R.; Mine, Y. Antioxidant activity of enzymatic hydrolysates from eggshell membrane proteins and its protective capacity in human intestinal epithelial Caco-2 cells. J. Funct. Foods 2014, 10, 35-45. [CrossRef]

41. Kuerban, A.; Al-Malki, A.L.; Kumosani, T.A.; Sheikh, R.A.; Al-Abbasi, F.A.M.; Alshubaily, F.A.; Abulnaja, K.O.; Moselhy, S.S. Identification, protein antiglycation, antioxidant, antiproliferative, and molecular docking of novel bioactive peptides produced from hydrolysis of Lens culinaris. J. Food Biochem. 2020, 44, e13494. [CrossRef] [PubMed]

42. Tonolo, F.; Moretto, L.; Ferro, S.; Folda, A.; Scalcon, V.; Sandre, M.; Fiorese, F.; Marin, O.; Bindoli, A.; Rigobello, M.P. Insight into antioxidant properties of milk-derived bioactive peptides in vitro and in a cellular model. J. Pept. Sci. 2019, 25, e3162. [CrossRef]

43. Tonolo, F.; Sandre, M.; Ferro, S.; Folda, A.; Scalcon, V.; Scutari, G.; Feller, E.; Marin, O.; Bindoli, A.; Rigobello, M.P. Milk-derived bioactive peptides protect against oxidative stress in a Caco-2 cell model. Food Funct. 2018, 9, 1245-1253. [CrossRef]

44. Admassu, H.; Gasmalla, M.A.A.; Yang, R.; Zhao, W. Bioactive Peptides Derived from Seaweed Protein and Their Health Benefits: Antihypertensive, Antioxidant, and Antidiabetic Properties. J. Food Sci. 2017, 83, 6-16. [CrossRef]

45. La Paz, S.M.-D.; Rodriguez-Martin, N.M.; Villanueva, A.; Pedroche, J.; Cruz-Chamorro, I.; Millan, F.; Millan-Linares, M.C. Evaluation of Anti-Inflammatory and Atheroprotective Properties of Wheat Gluten Protein Hydrolysates in Primary Human Monocytes. Foods 2020, 9, 854. [CrossRef]

46. Rodriguez-Martin, N.M.; La Paz, S.M.-D.; Toscano, R.; Grao-Cruces, E.; Villanueva, A.; Pedroche, J.; Millan, F.; Millan-Linares, M.C. Hemp (Cannabis sativa L.) Protein Hydrolysates Promote Anti-Inflammatory Response in Primary Human Monocytes. Biomolecules 2020, 10, 803. [CrossRef] [PubMed] 
47. Turner, M.D.; Nedjai, B.; Hurst, T.; Pennington, D.J. Cytokines and chemokines: At the crossroads of cell signalling and inflammatory disease. Biochim. Biophys. Acta Bioenerg. 2014, 1843, 2563-2582. [CrossRef]

48. Zanoni, C.; Aiello, G.; Arnoldi, A.; Lammi, C. Investigations on the hypocholesterolaemic activity of LILPKHSDAD and LTFPGSAED, two peptides from lupin $\beta$-conglutin: Focus on LDLR and PCSK9 pathways. J. Funct. Foods 2017, 32, 1-8. [CrossRef]

49. Millán-Linares, M.D.C.; Millán, F.; Pedroche, J.; Yust, M.D.M. GPETAFLR: A new anti-inflammatory peptide from Lupinus angustifolius L. protein hydrolysate. J. Funct. Foods 2015, 18, 358-367. [CrossRef] 